\section{Productivity and Characteristics of American Elderberry in Response to Various Pruning Methods}

\author{
Andrew L. Thomas ${ }^{1}$ \\ University of Missouri, Southwest Research Center, 14548 Highway H, Mt. \\ Vernon, MO 65712
}

Patrick L. Byers

University of Missouri, Cooperative Extension Service, Springfield, MO 65802

\author{
Mark R. Ellersieck \\ University of Missouri, Agricultural Experiment Station, Columbia, MO \\ 65211
}

Additional index words. Sambucus, fruit, yield, cultivar, management, phenology

\begin{abstract}
American elderberry [Sambucus canadensis L.; Sambucus nigra ssp. canadensis (L.) Bolli] is being increasingly cultivated in North America for its edible fruit and flowers, yet it remains largely undeveloped as a horticultural crop. Elderberry is a shrub that produces fruit on both new and old wood, thereby offering unique pruning management opportunities and challenges. The objective of this study was to document the response of American elderberry to various pruning methods in terms of flowering, fruit yield, phenology, plant growth, and incidence of disease and arthropod pests and to consider the impact of various pruning methods on horticultural management. Four pruning treatments (annual removal of all shoots, biannual removal of all shoots, annual selective pruning, and no pruning) were studied among three cultivars at two Missouri sites over 5 years. Although significant interactions among experimental effects made interpretation challenging, several trends were evident. Annual selective pruning was an excellent way to manage elderberries with mean yields of $1086 \mathrm{~g} / \mathrm{plant}$ across all experimental parameters; however, pruning to the ground annually or biannually also resulted in satisfactory yields $(855$ and $1085 \mathrm{~g} / \mathrm{plant}$, respectively) with a fraction of pruning labor involved. Pruning plants to the ground consistently resulted in fewer, but larger, fruiting cymes compared with selectively pruned or unpruned plants, which may be important in terms of harvest efficiency. Pruning treatment generally affected the time of flowering and fruit ripening; plants that flowered only on new stems (after removal of all shoots) ripened fruit 14 to 21 days later than plants that fruited on old wood. Although annually pruned plants generally yielded lower, the plants remained vigorous and productive, and this pruning management technique may have numerous advantages over other pruning methods.
\end{abstract}

The American elderberry [Sambucus canadensis L.; Sambucus nigra ssp. canadensis (L.) Bolli] is a common shrub native to eastern and midwestern North America that produces edible flowers and berries. The fruit is used to make jam, jelly, syrup, food coloring, beverages, and wine, whereas the flowers are consumed cooked, in beverages, wine, or as an infusion. The medicinal attributes of elderberry are becoming well known (e.g., Charlebois et al., 2010; Thomas et al., 2008; Zakay-Rones et al., 1995, 2004), and demand for nonfermented elderberry juice concentrates taken as a nutraceutical or dietary supplement is increasing (J. Brewer, Wyldewood Cellars, Mulvane, KS, pers. comm.). Many U.S. elderberry processors rely on

Received for publication 6 Jan. 2009. Accepted for publication 3 Mar. 2009.

We thank John Avery, Chase Davis, and Diane Thompson.

${ }^{1}$ To whom reprint requests should be addressed; e-mail thomasal@missouri.edu. ture and botany (Charlebois et al., 2010) has provided an updated and comprehensive summary of current elderberry knowledge. Some guidance on cultivating American elderberry may be gleaned from studies on the European elder [Sambucus nigra L.; Sambucus nigra ssp. nigra (L.) Bolli]; however, the two species are morphologically different, and such information is also limited (e.g., Kaack, 1988, 1990; Waźbińska et al., 2004). No literature is available on the effect of pruning either species of elderberry in terms of productivity, phenology, or pest management.

The American elderberry is a large, vigorous, multistemmed shrub that produces fruit on the current season's growth as well as older wood. For simplicity, we use the terms "primary" and "secondary" to refer to new flowering shoots that emerge annually from the soil and flowering stems that arise from older woody shoots, respectively. In general, American elderberry primary shoots emerge each spring from rhizomes that spread aggressively from the original growing point or to replace secondary shoots that are damaged, killed, or removed. Primary shoots end in a single large inflorescence that opens a few to several days later than inflorescences on secondary stems, which tend to be smaller and more numerous. The very different morphology of these two types of fruiting stems in elderberry has important management implications in terms of productivity, uniformity of ripening, potential for mechanical harvest, harvest efficiency, pruning labor, and pest management. The European elder is taller and tends to spread less aggressively from rhizomes compared with $S$. canadensis; this characteristic permits pruning $S$. nigra into a singletrunked plant that can be coppiced to the same point at 1 to $2 \mathrm{~m}$ annually. We do not believe that $S$. canadensis could be grown successfully in this manner, but this concept certainly merits research.

Given the potential productivity of primary shoot fruiting in American elderberry, the simplest and least costly pruning management technique might be to prune the plants to the ground each spring, perhaps most efficiently with a motorized or tractormounted sickle bar cutter. Well-established plants managed in this manner should produce good yields annually while maintaining long-term vigor and productivity, but yield may be somewhat compromised compared with a much more labor-intensive selective pruning system in which only old, unproductive wood is removed each winter. The objectives of this study were to evaluate that hypothesis and to ascertain the characteristics and productivity of elderberry in response to four pruning methods in terms of fruit yield, phenology, plant growth, and arthropod pest and disease incidence.

\section{Materials and Methods}

This elderberry pruning management study was conducted over 5 years after a 
2-year establishment period (2000 to 2006) at two locations in Missouri. The sites were at the University of Missouri's Southwest Research Center in southwest Missouri near

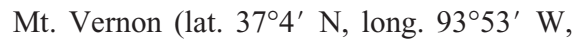
alt. $378 \mathrm{~m}$ ) and Missouri State University's State Fruit Experiment Station in southcentral Missouri near Mountain Grove (lat. $37^{\circ} 13^{\prime} \mathrm{N}$, long. $92^{\circ} 26^{\prime} \mathrm{W}$, alt. $434 \mathrm{~m}$ ). The two sites are $140 \mathrm{~km}$ apart. Annual precipitation averages $1117 \mathrm{~mm}$ at Mt. Vernon and $1148 \mathrm{~mm}$ at Mountain Grove. The soil at Mt. Vernon was a Hoberg silt loam (fine-loamy, siliceous, mesic Mollic Fragiudalfs) that is upland, deep, gently sloping, and moderately well drained with a fragipan at 40 to $90 \mathrm{~cm}$ (Hughes, 1982). Soil tests at Mt. Vernon indicated $\mathrm{pH} 5.7$, organic matter $3.6 \%$, cation exchange capacity $13.5 \mathrm{mEq} / 100 \mathrm{~g}$, low levels of phosphorus (P), and adequate levels of potassium $(\mathrm{K})$, calcium $(\mathrm{Ca})$, and magnesium $(\mathrm{Mg})$ based on recommendations for blackberry (Rubus sp.) production. The soil at Mountain Grove was a Viraton silt loam (fine-loamy, siliceous, mesic Typic Fragiudalfs) with very similar properties (Robertson, 1981). A soil test indicated $\mathrm{pH} 6.3$, organic matter $2.4 \%$, cation exchange capacity $9.1 \mathrm{mEq} / 100 \mathrm{~g}$, low levels of $\mathrm{P}$, and high levels of $\mathrm{K}, \mathrm{Ca}$, and $\mathrm{Mg}$. The chief difference between the two soils is that the Hoberg generally has a darker, thicker, softer surface horizon with more organic matter compared with the Viraton. At Mountain Grove, the soil was moved into $20-\mathrm{cm}$ raised soil ridges before planting, whereas flat, undisturbed ground was used at Mt. Vernon. Worth noting is that the Mountain Grove site was $\approx 50 \mathrm{~m}$ downhill from a large (2-ha) irrigation lake, which likely influenced subsurface hydrology there. Both planting sites were prepared by killing existing vegetation in the planting rows with glyphosate herbicide before planting. Alleyways of tall fescue grass (Festuca arundinacea Schreb.) were maintained and mowed at both locations.

The three elderberry cultivars used in the study included one long-established cultivar
(Adams II) and two new wild selections from Missouri that were under evaluation for their promising horticultural potential ('Bob Gordon' and 'Netzer'). The origin and morphology of these two elderberry selections were initially described in Thomas and Byers (2000), in which 'Bob Gordon' was tested as 'Gordon B'. This cultivar was also called 'Gordon B' in Finn et al. (2008) and elsewhere. The original source for our 'Adams II' material was Pense Nursery (Mountainburg, AR).

Hardwood and softwood cuttings were collected from our own mother plants in Spring 2000, rooted in a greenhouse, and then transplanted to both sites in June 2000. Experimental plots contained three plants each, planted $1.2 \mathrm{~m}$ apart. Plots were separated by $2.4 \mathrm{~m}$ within and $3.1 \mathrm{~m}$ between rows. The total number of plants per site was 144 with each planting covering $\approx 0.10$ ha. The three cultivars and four pruning treatments were assigned to plots in a completely randomized experimental design with four replications of each cultivar-pruning treatment combination. The four pruning treatments included 1) pruning plants to the ground annually in early spring; 2) pruning to the ground every other spring (biannually); 3 ) annual selective pruning, defined as removal of old unproductive or poor-quality wood and tipping back to strong stems at $\approx 1$ $\mathrm{m}$; and 4) unpruned. Both plantings were fertilized each spring with $56 \mathrm{~kg} \cdot \mathrm{ha}^{-1} \mathrm{~N}$ (as $\mathrm{NH}_{4} \mathrm{NO}_{3}$ ). When rainfall was lacking during the growing seasons, plants were irrigated by drip lines to provide 2.5 to $4.0 \mathrm{~cm}$ water per week. Weeds were managed with mulch, hand-weeding, and glyphosate herbicide, and no insecticides or fungicides were used. All plants were allowed to grow normally without pruning in 2000 and 2001, except that inflorescences were removed to encourage root and structural growth. After this 2-year establishment period, all plants in all plots were pruned to the ground in early Spring 2002 to initiate the study. Thereafter, the biannual pruning treatments were ap- plied in Spring 2004 and 2006. Data were collected over 5 years from 2002 to 2006 . Data included fruit yield, cyme number and size, individual berry weight, arthropod pest and disease incidence, plant height, and phenological characteristics such as bloom time, fruit ripening, and harvest date. Individual berry weights were determined by counting and weighing, in bulk, 50 random ripe berries (fresh weight) per treatment plot. Eriophyid mites (Eriophyidae) and bacterial leafspot [tentatively identified as Pseudomonas viridiflava Burkholder (Dowson)] were assessed multiple times throughout the growing seasons in 2004 to 2006 using a subjective scale of 1 to 5 , in which $1=$ severe damage and $5=$ no occurrence.

Statistical analyses were conducted using split plots in time and fixed locations. The experimental unit was the entire three-plant plot; however, for simplicity and practicality, all production data are presented on a singleplant basis. Data were analyzed using the "Mixed" procedure (Proc Mixed; SAS Institute, Cary, NC), with means separated by Fisher's protected least significant difference at the $P \leq 0.05$ level. Least significant differences were calculated using the SE of the differences of least square means and the appropriate $t$ level for the degree of freedom for each variable $(P \leq 0.05)$.

\section{Results and Discussion}

The elderberry plantings at both locations survived and performed well for the duration of the study, except that part of the 'Netzer' fruit crop at Mountain Grove was destroyed by birds in 2003. Table 1 displays broad and generalized mean results across the entire study. Significant differences in fruit production, cyme number and size, berry weight, plant height, and eriophyid mite and bacterial leafspot incidence were detected in varying degrees between the two sites and among the three cultivars, the four pruning treatments, and the 5 years. Across all experimental parameters, mean fruit yields generally increased

Table 1. Mean yield, cyme production, plant height, and pest response from American elderberry pruning study at Mountain Grove (MG) and Mt. Vernon (MV), MO.

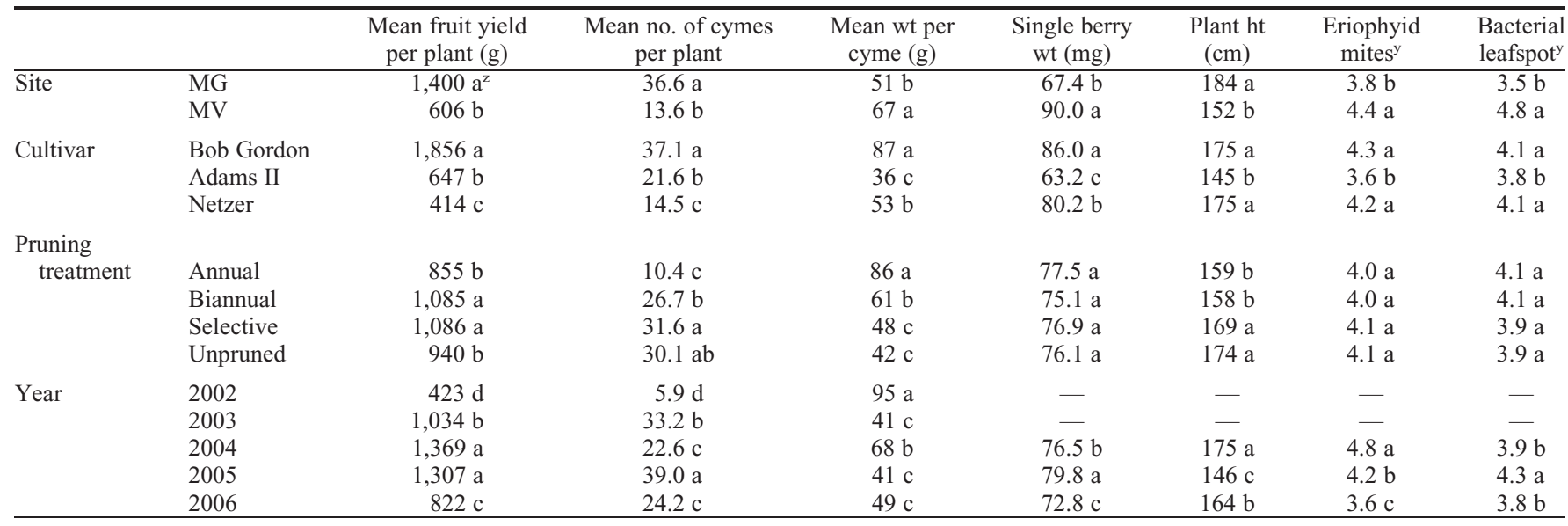

${ }^{2}$ Values within subcolumns having similar letters are not statistically different $(P \leq 0.05)$.

${ }^{\mathrm{y}}$ Scale 1 to $5: 1$ = severe damage; 5 = no damage. 
from 2002 and 2003 to maximum yields in 2004 and 2005 (overall mean maximum yield $1369 \mathrm{~g} /$ plant) and then declined in 2006. We do not know if this eventual decline was an anomaly or, if indeed, an elderberry orchard's highest productivity may be shortlived. Overall mean yields were significantly higher at Mountain Grove (1400 g/plant) compared with Mt. Vernon (606 g/plant). This substantial yield difference between sites is consistent with another elderberry study conducted at these two sites (Finn et al., 2008) but is difficult to understand. The climate, management, and soils were generally similar at both locations, but the plants at Mountain Grove were established on raised soil ridges very near a large irrigation lake. The ridges may have improved soil aeration, whereas the lake may have increased subsurface water availability to the plants; both of these factors may have contributed to the higher yields at Mountain Grove. With an overall mean yield of $1856 \mathrm{~g} /$ plant, the experimental cultivar Bob Gordon yielded nearly triple that of 'Adams II' and over four times that of 'Netzer' across all experimental parameters. Overall, annually pruned plants and unpruned plants yielded significantly less than selectively pruned or biannually pruned plants.

During the first year's (2002) harvest, mean number of cymes per plant (5.9) was lowest and individual cyme weight $(95 \mathrm{~g})$ the greatest (Table 1). This was certainly because all plants had been pruned to the ground that spring to initiate the study and that all growth and flowering among all plants occurred on primary shoots that ended in single, large inflorescences. When considering cyme number and size in subsequent years, the annually pruned plants consistently produced fewer, larger cymes compared with biannually pruned, selectively pruned, or unpruned plants. In Table 1, the data for cyme number and size in biannually pruned plants are, of course, means across years when plants were pruned and not pruned and clearly reflect an intermediate result between annually pruned and selectively pruned or unpruned plants. Berry size was unaffected by pruning but did vary by cultivar, location, and year. 'Bob Gordon' produced the largest mean berry weight overall at $86.0 \mathrm{mg}$. Mt. Vernon, which had lower overall fruit yields, produced larger berries $(90.0 \mathrm{mg})$ compared with Mountain Grove $(67.4 \mathrm{mg})$. Plant height was also generally influenced by the various experimental parameters. Plants were taller at Mountain Grove; the cultivars Bob Gordon and Netzer were taller than 'Adams II'; and plants were taller in 2004 compared with 2005 and 2006. Over multiple parameters, annually pruned and biannually pruned plants were slightly but significantly shorter (159 and $158 \mathrm{~cm}$, respectively) compared with selectively pruned and unpruned plants (169 and $174 \mathrm{~cm}$ ).

Eriophyid mite occurrence was generally unaffected by pruning but varied among locations (greater infestation at Mountain Grove), cultivars ('Bob Gordon' and 'Netzer' less affected than 'Adams II'), and years (generally increased incidence as years progressed). Eriophyid mites are a common and important pest of elderberry, but little is known about their taxonomy, life cycles, or management. Vaněčková-Skuhravá (1996) reported that the eriophyid mite Epitrimerus trilobus Nalepa overwinters within and beneath leaf buds of $S$. nigra in the Czech Republic. The same mite species has been documented as occurring on $S$. canadensis in North America (Davis et al., 1982). Eriophyid mites are generally known to overwinter in cracks and crevices of stems and bud scales. This led to a hypothesis that annual removal and destruction of overwintered stems might remove a significant source of mite proliferation, but this was not evident in our study. Many eriophyid mite species are spread by wind and it is possible that reinfestation occurred from neighboring unpruned plots within our study or from other sources. Two important insect pests that might also be managed through annual removal of stems are the elder shoot borer (Achatodes zeae Harris), which overwinters as eggs on stems (Buriff and Still, 1972; Silver, 1933; Solomon, 1995), and the elder borer beetle (Desmocerus palliatus Forester), which overwinters as pupae in the crown and lower stem areas of the plant (Solomon, 1995). We did not address these two pests in this study, but because elderberry flowers and fruit can be reliably produced with annual removal of stems, this approach to elderberry pest management should be studied further. Although pruning treatment did not affect bacterial leafspot incidence in this study, the effect of various pruning regimens on plant structure and air circulation within the plant canopy may be important considerations with this disease and potentially with various fungal pathogens that attack elderberry.

Significant interactions among experimental effects were detected across most production and phenological factors and are detailed in Table 2. Many of these interactions are profound and difficult to understand or explain and were no doubt exacerbated by the substantial differences in experimental results between the two sites and among the three cultivars. These significantly differing results and the high degree of interaction among experimental effects suggest that elderberry is highly responsive to environment and management and that genetic development and improvement of elderberry is a realistic goal. Finn et al. (2008) observed similar substantial variability in experimental effects, including genotype-by-environment interactions, in a separate elderberry study at these same two sites.

Because of the substantial variability and interactions among sites and cultivars, and because of the need to specifically examine long-term year-to-year responses of the elderberry plants to our pruning treatments, we present detailed experimental results in three tables (Tables 3-5) sorted by the cultivars Adams II, Bob Gordon, and Netzer, respectively. The least significant difference (LSD) for each of the two sites per table was calculated separately.

'Bob Gordon' plants (Table 4) that received biannual pruning treatments produced significantly higher yields the year after pruning (2003 and 2005) compared with annual pruning at both sites. Similar yield differences were evident with 'Netzer' at

Table 2. Statistical interactions among site, cultivar, pruning treatment, and year for production and phenological characteristics.

\begin{tabular}{|c|c|c|c|c|c|c|c|c|c|}
\hline Effect & $\begin{array}{l}\text { Mean yield } \\
\text { per plant }\end{array}$ & $\begin{array}{c}\text { Mean no. of } \\
\text { cymes per plant }\end{array}$ & $\begin{array}{l}\text { Mean wt } \\
\text { per cyme }\end{array}$ & $\begin{array}{c}\text { Single berry } \\
\text { wt }\end{array}$ & First bloom & Full bloom & First ripe & Full ripe & Plant ht \\
\hline Cultivar (C) & $* * *$ & $* * *$ & $* * *$ & $* * *$ & $* * *$ & $* * *$ & $* * *$ & $* * *$ & $* * *$ \\
\hline $\mathrm{S} \times \mathrm{C}$ & $* * *$ & $* * *$ & $* * *$ & $* * *$ & $*$ & $* * *$ & $* * *$ & NS & $* * *$ \\
\hline treatment $(\mathrm{P})$ & * & $* * *$ & $* * *$ & NS & $* * *$ & $* * *$ & $* * *$ & $* * *$ & $* * *$ \\
\hline $\mathrm{S} \times \mathrm{P}$ & NS & $* * *$ & NS & ** & $* * *$ & $* *$ & NS & NS & $* * *$ \\
\hline $\mathrm{C} \times \mathrm{P}$ & NS & $* * *$ & $* * *$ & $*$ & NS & $* * *$ & $* *$ & $* * *$ & $* * *$ \\
\hline $\mathrm{C} \times \mathrm{Y}$ & $* * *$ & $* * *$ & $* * *$ & NS & $* *$ & $* *$ & $* * *$ & $* * *$ & NS \\
\hline $\mathrm{S} \times \mathrm{C} \times \mathrm{Y}$ & $* * *$ & $* * *$ & $* * *$ & NS & NS & $*$ & $*$ & $*$ & NS \\
\hline $\mathrm{P} \times \mathrm{Y}$ & $* * *$ & $* * *$ & $* * *$ & $* * *$ & $* * *$ & $* * *$ & $* * *$ & $* * *$ & $* * *$ \\
\hline $\mathrm{S} \times \mathrm{P} \times \mathrm{Y}$ & $* * *$ & $* * *$ & NS & NS & $* *$ & $* *$ & $* *$ & NS & $* * *$ \\
\hline $\mathrm{C} \times \mathrm{P} \times \mathrm{Y}$ & $* * *$ & $* * *$ & NS & $*$ & NS & NS & ** & ** & NS \\
\hline $\mathrm{S} \times \mathrm{C} \times \mathrm{P} \times \mathrm{Y}$ & $* *$ & $*$ & $*$ & * & NS & NS & $*$ & ** & NS \\
\hline
\end{tabular}

${ }_{\mathrm{NS}}, *, * * * * *=$ nonsignificant, significant at $P<0.05, P<0.01, P<0.001$, respectively. 
Table 3. Yield, cyme production, phenology, and plant height of American elderberry 'Adams II' at Mt. Vernon and Mountain Grove, MO, from 2003 to 2006 in response to four pruning regimens.

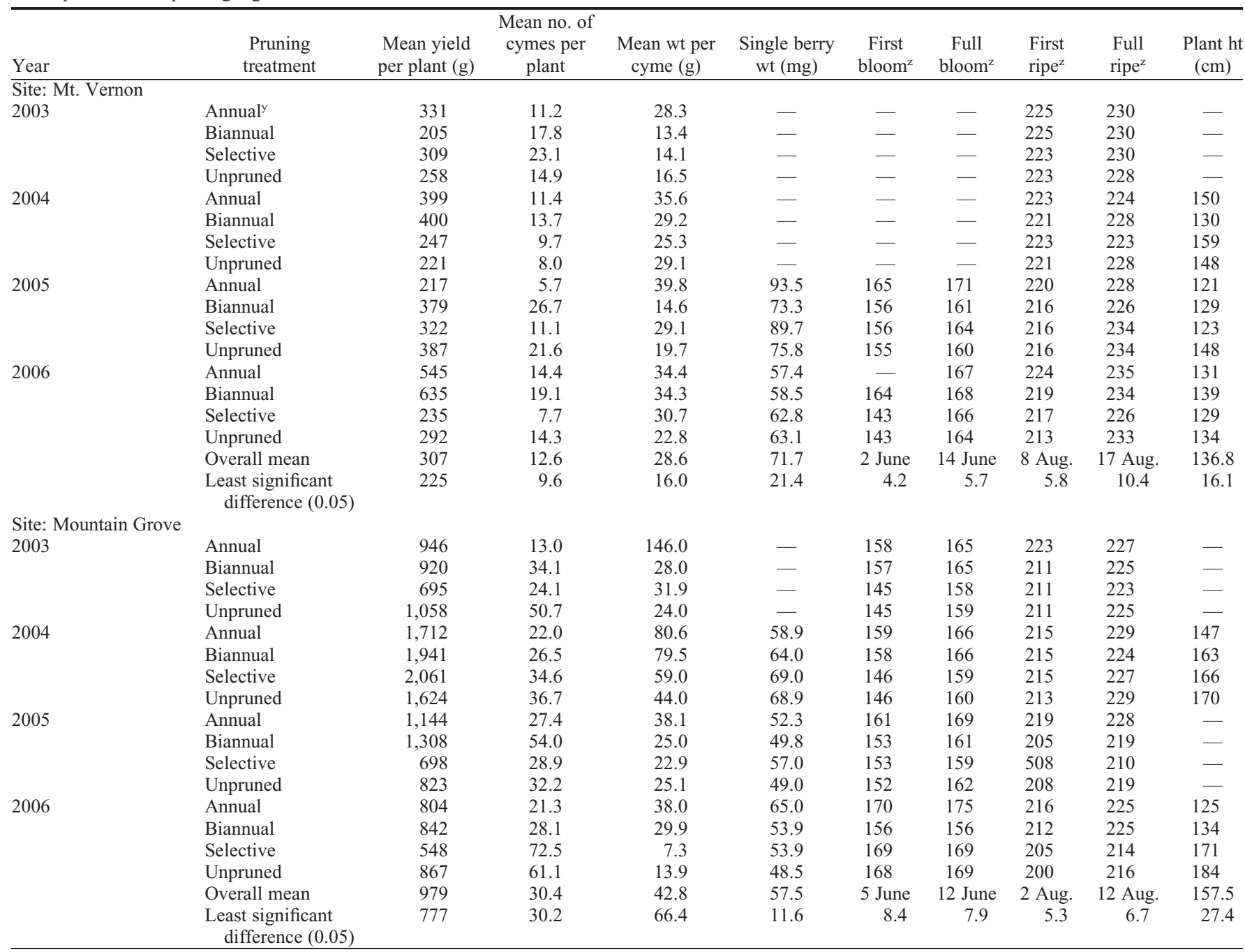

\footnotetext{
${ }^{\mathrm{z}}$ Numerical day of year beginning with 1 Jan.
}

${ }^{y}$ After establishment, all plants in all plots were cut to the ground in 2002 to initiate the study. Thereafter, plants with biannual pruning treatments were cut to the ground in Spring 2004 and 2006.

both sites (Table 5). 'Adams II', however, did not appear to respond favorably (or unfavorably) to the biannual pruning treatment during the year after pruning (Table 3). Annually pruned plants generally produced good and reliable yields in our study. They tended to yield less than plants with other pruning treatments, but this was not consistent across sites and cultivars, and in a few cases (e.g., 'Bob Gordon' at Mountain Grove in 2004; Table 4), they actually yielded more than plants pruned otherwise. In only a few cases did selectively pruned plants yield significantly more than other treatments, and likewise, in only a few cases did unpruned plants yield less, as might have been expected. We expect that plants left unpruned for durations longer than this study would eventually begin to decline as a result of accumulation of old, unproductive wood and pathogenic organisms. The high amount of variability (and high LSDS) among fruit yields across this study does not permit us to definitively conclude that one elderberry pruning methodology is consistently superior across site and genetic parameters for yield. The profound and inconsistent differences in yield response to pruning by these three elderberry genotypes underscore the need to study and develop management recommendations tailored to specific cultivars and specific sites (Finn et al., 2008).

Cyme number and size were more clearly and consistently affected by pruning treatments than were yields. Annual pruning generally resulted in the production of fewer, larger cymes across both locations and all three cultivars. This same response is evident on plants that were pruned to the ground biannually; during the year of pruning, fewer larger cymes were produced, with cyme number increasing and cyme size decreasing the subsequent year. For example, with 'Bob Gordon' at Mountain Grove (Table 4), the biannually pruned plots that were pruned in 2004 produced similar number and size of cymes (24.0 and $132.4 \mathrm{~g}$, respectively) compared with annually pruned plants (27.5 and $174.3 \mathrm{~g}$ ), and both of these treatments produced significantly fewer, larger cymes compared with other treatments. The next year, 2005, the biannually pruned plants behaved similarly to the selectively pruned and unpruned plants in terms of cyme size and number (129.4 and $38.1 \mathrm{~g}$, respectively). These results suggest that cyme number and size are directly affected and can be precisely manipulated by pruning. Indeed, this aspect of elderberry pruning management may be more important than yield effects. In most cases, producers would prefer harvesting fewer, larger cymes rather than more numerous, smaller cymes in terms of harvest efficiency and postharvest handling. Individual berry weights were largely unaffected in a consistent manner by pruning treatment.

Phenological characteristics of elderberry were, in many cases, significantly affected by the pruning treatments in this study. The predominant trend agreed with our observations and hypothesis that pruning plants to the ground delays anthesis and fruit ripening by 
Table 4. Yield, cyme production, phenology, and plant height of American elderberry 'Bob Gordon' at Mt. Vernon and Mountain Grove, MO, from 2003 to 2006 in response to four pruning regimens.

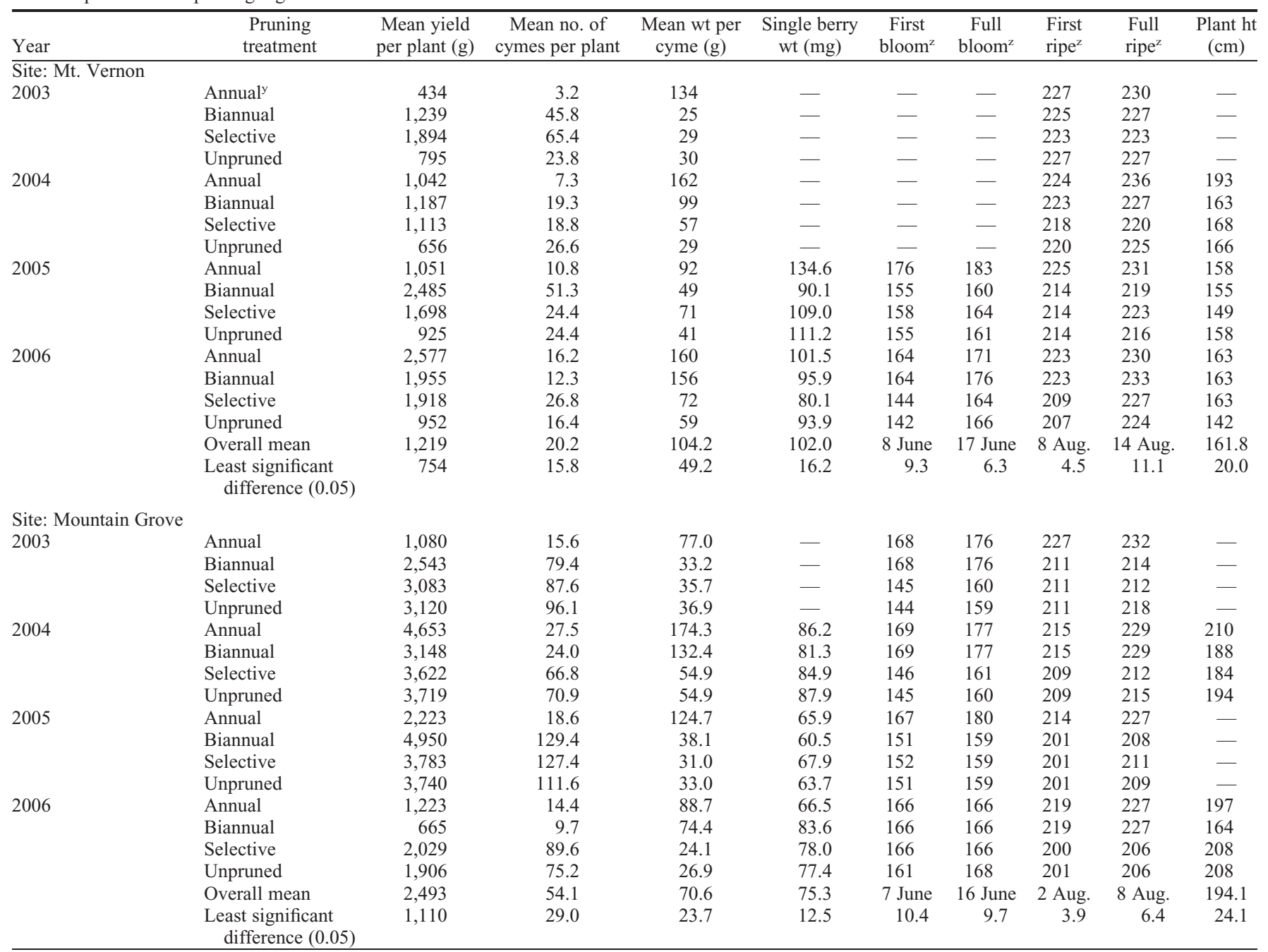

${ }^{\mathrm{z} N u m e r i c a l}$ day of year beginning with 1 Jan.

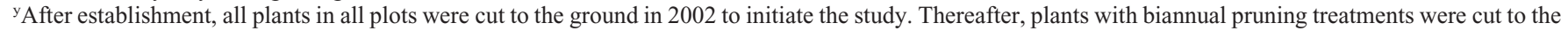
ground in Spring 2004 and 2006.

several days. For example, with 'Bob Gordon' at Mountain Grove (Table 4), both annually pruned plants and biannually pruned plants during the years of pruning (2004 and 2006) ripened their fruit 14 to $17 \mathrm{~d}$ later in 2004 and 21 d later in 2006 compared with selectively pruned or unpruned plants. During 2005, when only the annually pruned plants were pruned to the ground, those plants ripened their fruit 16 to 19 d later than all other pruning treatments, which were not different from each other. However, such differences were not always consistent or significant. Our phenological results for the three pruning regimens other than annual pruning may have been somewhat "averaged" because we collected anthesis and fruit ripening data across the entire plot, which likely included both primary and secondary stems. Because pruning plants to the ground generally delayed ripening, it also tended to reduce the number of harvests and therefore focused the harvest window into a narrower timeframe as the growing season concluded in August (data not shown). Fur- thermore, because all growth on such plants is primary shoots, greater uniformity of flowering, fruiting, and ripening is achieved. For most producers, this system of pruning management would likely increase harvest and postharvest efficiency depending on their goals and resources. Such producers may consider a potentially lower overall yield a reasonable tradeoff for the greatly simplified pruning and harvest. Other producers, for example, those with limited labor or resources for harvest and postharvest handling, may prefer a longer, more gradual harvest that could likewise be manipulated by pruning. The harvest window may be more uniform and predictable with a given pruning regimen. Such uniformity of ripening and plant architecture would be especially important toward the development of mechanical harvest of elderberries.

Experimental differences in plant height at this level of detail were, again, quite variable. In a few cases [e.g., 'Adams II' and 'Netzer' at Mountain Grove (Tables 3 and 5)], annually and biannually pruned plants were shorter than plants pruned otherwise, but in general, differences in end-of-season plant height resulting from various pruning methods were inconsistent and insignificant. Pruning plants to the ground seems to have little consequence on ultimate plant height.

Other aspects of yield management and crop protection such as bird predation may also be directly affected by pruning. For example, in our experience, birds tend to favor fruit borne on stiff, upright stems rather than on procumbent branches. Primary elderberry stems that are less woody and rigid than secondary branches and that bear single, large, heavy fruit-laden cymes tend to bend toward the ground where birds are less inclined to dwell. The potential impact of a longer exposure of ripening fruit to birds, insects, diseases, and weather (hail, for example) caused by pruning-induced delayed fruit ripening should also be considered.

Although this study provides new information on potential pruning strategies for manipulating elderberry production, questions remain concerning the long-term implica- 
Table 5. Yield, cyme production, phenology, and plant height of American elderberry 'Netzer' at Mt. Vernon and Mountain Grove, MO, from 2003 to 2006 in response to four pruning regimens.

\begin{tabular}{|c|c|c|c|c|c|c|c|c|c|c|}
\hline Year & $\begin{array}{l}\text { Pruning } \\
\text { treatment }\end{array}$ & $\begin{array}{l}\text { Mean yield } \\
\text { per plant }(\mathrm{g})\end{array}$ & $\begin{array}{c}\text { Mean no. of cymes } \\
\text { per plant }\end{array}$ & $\begin{array}{l}\text { Mean wt per } \\
\text { cyme }(\mathrm{g})\end{array}$ & $\begin{array}{l}\text { Single berry } \\
\text { wt (mg) }\end{array}$ & $\begin{array}{c}\text { First } \\
\text { bloom }^{z}\end{array}$ & $\begin{array}{c}\text { Full } \\
\text { bloom }^{2}\end{array}$ & $\begin{array}{l}\text { First } \\
\text { ripe }^{z}\end{array}$ & $\begin{array}{l}\text { Full } \\
\text { ripe }^{z}\end{array}$ & $\begin{array}{l}\text { Plant ht } \\
(\mathrm{cm})\end{array}$ \\
\hline \multirow{2}{*}{2003} & Biannual & 673 & 25.3 & 26.6 & - & - & - & 225 & 228 & - \\
\hline & Unpruned & 596 & 25.3 & 23.7 & - & - & - & 225 & 230 & - \\
\hline \multirow[t]{2}{*}{2004} & Annual & 179 & 2.2 & 85.0 & - & - & - & 240 & 240 & 156 \\
\hline & Biannual & 172 & 2.5 & 74.6 & - & - & - & 240 & 240 & 153 \\
\hline \multirow[t]{4}{*}{2005} & Annual & 17 & 0.3 & 46.7 & 108.7 & 183 & 191 & 257 & 257 & 123 \\
\hline & Biannual & 593 & 11.7 & 48.7 & 102.6 & 165 & 171 & 228 & 234 & 161 \\
\hline & Selective & 342 & 6.5 & 48.6 & 108.2 & 163 & 173 & 231 & 234 & 142 \\
\hline & Unpruned & 488 & 10.0 & 57.4 & 109.0 & 163 & 168 & 222 & 231 & 183 \\
\hline \multirow[t]{3}{*}{2006} & Annual & 143 & 2.8 & 52.0 & 89.4 & 169 & 190 & 235 & 237 & 151 \\
\hline & Biannual & 283 & 3.8 & 68.8 & 100.4 & 176 & 186 & 243 & 252 & 149 \\
\hline & Selective & 213 & 4.6 & 47.0 & 81.8 & 164 & 169 & 228 & 244 & 161 \\
\hline \multirow{4}{*}{2003} & Annual & - & - & - & - & 167 & 179 & - & - & - \\
\hline & Biannual & - & - & - & - & 170 & 178 & - & - & - \\
\hline & Selective & - & - & - & - & 156 & 164 & - & - & - \\
\hline & Unpruned & 665 & 16.9 & 39.4 & - & 156 & 163 & 225 & - & - \\
\hline \multirow[t]{4}{*}{2004} & Annual & 1,024 & 10.9 & 93.0 & 80.3 & 168 & 180 & 215 & 236 & 201 \\
\hline & Biannual & 1,099 & 11.5 & 105.3 & 80.9 & 171 & 179 & 215 & 236 & 211 \\
\hline & Selective & 1,207 & 38.2 & 38.3 & 80.7 & 157 & 165 & 215 & 231 & 224 \\
\hline & Unpruned & 502 & 18.8 & 26.4 & 75.6 & 157 & 164 & 215 & 232 & 211 \\
\hline \multirow[t]{4}{*}{2005} & Annual & 146 & 5.3 & 25.8 & 62.0 & 174 & 181 & 229 & 229 & - \\
\hline & Biannual & 1,567 & 89.5 & 17.8 & 60.3 & 154 & 165 & 213 & 225 & - \\
\hline & Selective & 1,063 & 47.9 & 22.8 & 62.6 & 159 & 169 & 210 & 225 & - \\
\hline & Unpruned & 1,017 & 59.4 & 17.4 & 67.0 & 161 & 167 & 215 & 223 & - \\
\hline 2006 & Annual & 96 & 2.8 & 34.1 & 52.0 & 159 & 159 & 227 & 227 & 154 \\
\hline
\end{tabular}

${ }^{2}$ Numerical day of year beginning with 1 Jan.

${ }^{y}$ After establishment, all plants in all plots were cut to the ground in 2002 to initiate the study. Thereafter, plants with biannual pruning treatments were cut to the ground in Spring 2004 and 2006.

tions of pruning. Although we seem to be espousing the multiple benefits of pruning elderberry to the ground annually, we know little about the long-term implications of such a pruning regimen. For example, a quantity of stored carbohydrates is removed as a consequence of annual shoot removal, which may over time reduce vigor and productivity. Additional research on the short- and longterm implications of various pruning strategies and, in fact, on the productive longevity of elderberry plantings is needed.

\section{Literature Cited}

American Society for Horticultural Science. 1997. The Brooks and Olmo register of fruit and nut varieties. ASHS Press, Alexandria, VA.

Buriff, C.R. and G.W. Still. 1972. Seasonal activity of adult elder shoot borer as indicated by blacklight traps. J. Econ. Entomol. 65:1201-1202.

Charlebois, D., P.L. Byers, C.E. Finn, and A.L. Thomas. 2010. Elderberry: Horticulture, botany, potential. Hort. Rev. (Amer. Soc. Hort. Sci.) (in press).

Craig, D.L. 1978. Elderberry culture in eastern Canada. Info. Services, Agriculture Canada, Ottawa, Canada.
Davis, R., C.H.W. Flechtmann, J.H. Boczek, and H.E. Barké. 1982. Catalogue of eriophyid mites (Acari: Eriophyoidea). Warsaw Agricultural Univ. Press, Warsaw, Poland.

Finn, C.E., A.L. Thomas, P.L. Byers, and S. Serçe. 2008. Evaluation of American (Sambucus canadensis) and European (S. nigra) elderberry genotypes grown in diverse environments and implications for cultivar development. HortScience 43:1385-1391.

Hill, R.G. 1969. Elderberry evaluation studies. Ohio Agr. Res. Dev. Ctr. Res. Summary 37: 20-22.

Hill, R.G. 1970. Performance of elderberry cultivars. Ohio Agr. Res. Dev. Ctr. Res. Summary 46:39-42.

Hughes, H.E. 1982. Soil survey of Greene and Lawrence Counties, Missouri. USDA Soil Conservation Service, in cooperation with Missouri Agr. Expt. Sta, Columbia, MO.

Kaack, K. 1988. Effect of nitrogen, planting distance and time of harvest on yield and fruit quality of elderberry (Sambucus nigra L.). Tidsskr. Planteavl 92:79-82.

Kaack, K. 1990. Optimum values of nutrients in the leaves of elderberry (Sambucus nigra L.). Tidsskr. Planteavl 94:131-133.

Ritter, C.M. 1958. Responses of cultivated elderberry varieties to fertilizer and mulch treat- ments. Progress Report 195. Pennsylvania State Univ. Agr. Expt. Sta.

Ritter, C.M. and G.W. McKee. 1964. Elderberry: History, classification, and culture. Pennsylvania State Univ. Agr. Expt. Sta. Bul. 709.

Robertson, G.D. 1981. Soil survey of Wright County Missouri. USDA Soil Conservation Service, in cooperation with Missouri Agr. Expt. Sta., Columbia, MO.

Silver, J.C. 1933. Biology and morphology of the spindle worm, or elder borer. USDA Tech. Bul. 345 .

Skirvin, R.M. and A. Otterbacher. 1977. Elderberry cultivar performance in Illinois. Fruit Varieties J. 31:7-10.

Solomon, J.D. 1995. Guide to insect borers of North American broadleaf trees and shrubs. Agriculture Handbook 706, USDA Forest Service.

Thomas, A.L. and P.L. Byers. 2000. Multilocational elderberry cultivar and management study. Proc. Missouri Small Fruit Conf. 20:3740. Southwest Missouri State Univ., Springfield, MO.

Thomas, A.L., P.L. Byers, C.E. Finn, Y.C. Chen, G.E. Rottinghaus, A.M. Malone, and W.L. Applequist. 2008. Occurrence of rutin and chlorogenic acid in elderberry leaf, flower, and stem in response to genotype, environment, 
and season. In: Gardner, G. and L.E. Craker (eds.). Plants as food and medicine: The utilization and development of horticultural plants for human health. Acta Horticulturae 765:197206.

Vaněčková-Skuhravá, I. 1996. Life cycles of five eriophyid mites species (Eriophyoidea, Acari) developing on trees and shrubs. J. Appl. Entomol. 120:513-517.

Way, R.D. 1957. Cultivated elderberries. Farm Res. 23:15. New York State Agr. Expt. Sta., Geneva.
Way, R.D. 1967. Elderberry growing in New York State. Cornell Ext. Bul. 1177. New York State Agr. Expt. Sta., Geneva.

Way, R.D. 1981. Elderberry culture in New York State. New York's Food and Life Sciences Bul. No. 91. New York State Agr. Expt. Sta., Geneva.

Waźbińska, W., U. Puczel, and J. Senderowska. 2004. Yield in elderberry cultivars grown on two different soils in 1997-2003. J. Fruit and Ornamental Plant Res, Special Ed. 12:175-181.

Zakay-Rones, Z., E. Thom, T. Wollan, and J. Wadstein. 2004. Randomized study of the efficacy and safety of oral elderberry extract in the treatment of influenza $A$ and B virus infections. J. Intl. Med. Res. 32:132140.

Zakay-Rones, Z., N. Varsano, M. Zlotnik, O. Manor, L. Regev, M. Schlesinger, and M. Mumcuoglu. 1995. Inhibition of several strains of influenza virus in vitro and reduction of symptoms by an elderberry extract (Sambucus nigra L.) during an outbreak of influenza B Panama. J. Altern. Complement. Med. 1:361369. 